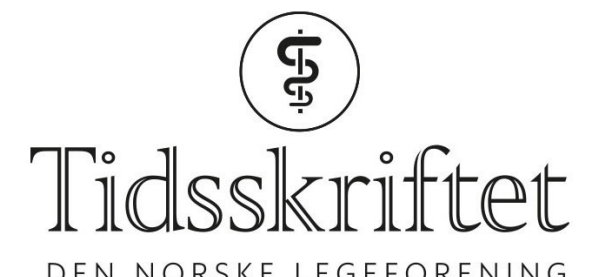

DEN NORSKE LEGEFORENING

\title{
Ledd, propriosepsjon og pasientfortellinger til å lære av
}

DEBATT

\section{TORBJØRN MÅSEIDE}

E-post: torbjornm@mimer.no

Torbjørn Måseide (f. 1940) er pensjonert kommuneoverlege og fastlege i Ulstein. Forfatter har fylt ut ICMJE-skjemaet og oppgir ingen interessekonflikter.

Gjennom en lang karriere som allmennpraktiker har pasientene lært meg enkelte triks som kan hjelpe ved skader og slitasje i ulike ledd. Kanskje andre kan ha glede av disse triksene?

Som ung og idrettsinteressert lege hadde jeg det medisinske ansvaret for mange aktive idrettsfolk. En av disse hadde vært gipset for en crusfraktur og var tilbake i vanlig trening noen uker etter at gipsen var fjernet da han ba meg se på ham.

Han forklarte at han fikk vondt oppe på vristen når han skulle løpe fort, samtidig som han følte at han ikke fikk tatt ut steget skikkelig. Han hadde også registrert at når han sto med hælen i gulvet og presset kneet fremover, kom kneet på den skadede siden vesentlig kortere frem enn kneet på den andre siden. Han hadde lite plager når han gikk eller jogget.

Min vurdering var at smerten i vristen måtte komme av at han ved rask løping presset leddene i fotroten i ytterstilling fordi dorsalfleksjonen i ankelleddet var nedsatt etter gipsingen. Han fikk råd om trening for å bedre bevegeligheten i ankelleddet.

Ved kontrollene etterpå ble fremgangen vurdert: Pasienten sto med stortåen $50 \mathrm{~cm}$ fra veggen og med hælen i gulvet og presset kneet så langt frem som mulig. Så ble avstanden fra kneskålen til veggen målt (fig 1). Dette er en nøyaktig og lett målbar undersøkelse på dorsalfleksjonen i ankelleddet. Ved å sammenligne dette målet med resultatet for det andre kneet kunne jeg vurdere hvor mye som var igjen før dorsalfleksjonen var normal. 


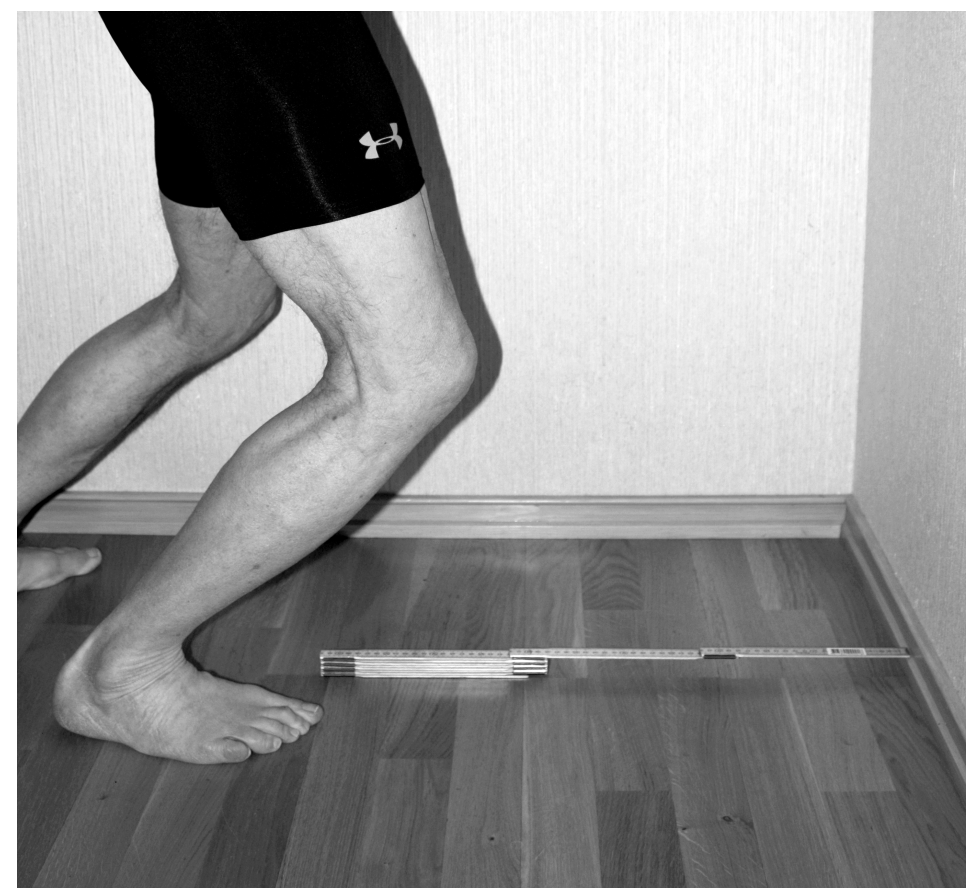

Figur 1 Forfatteren demonstrerer metoden for å måle leddutslag $i$ ankelen

Senere har jeg brukt denne undersøkelsen når jeg har fått pasienter med plager i ankelen etter brudd eller vrikking. Ved denne metoden blir leddet presset i ytterstilling, og det gir et mer nøyaktig mål for bevegeligheten enn det man finner ved undersøkelse på benk der man prøver å sammenligne de to anklene. Min erfaring er at plagene hos fysisk aktive personer først gir seg når forskjellen på de to sidene ikke er større enn 1-1,5 cm.

Ved nedsatt dorsalfleksjon i ankelen er det nesten alltid også nedsatt plantarfleksjon og pronasjon og supinasjon. Plantarfleksjonen får man oversikt over når pasientene sitter på benken med flekterte ankler og prøver å sette seg ned med setet mot hælene. Ved nedsatt plantarfleksjon vil pasienten lene seg over mot den friske siden.

Som opptrening av bevegelse i ankelleddet har jeg ofte gitt råd om en halvtimes tur i utmark eller andre steder med ujevnt underlag 3-4 ganger i uken og å presse ankelen i dorsalfleksjon flere ganger daglig når man står i en trapp. Min erfaringen er at dette gir rask bedring av bevegeligheten i ankelleddet.

\section{Leddsans og ulendt terreng}

En annen pasient spurte meg hvorfor han etter ankelskaden måtte se mer ned på underlaget når han gikk i utmark enn før han ble skadet. Han hadde også merket at han hadde vansker med å ta på seg sokker og sko uten å støtte seg når han sto på det skadede benet. Bevegeligheten i ankelen var blitt normal. Forklaringen måtte være at leddsansen i ankelen var redusert etter skaden. Den samme pasienten nevnte for meg i en senere konsultasjon at han 3-4 måneder etter skaden merket at han ikke lenger behøvde å se seg for på samme måten når han gikk i ulendt terreng.

Opplysningene fra disse to pasientene, og registreringen av hvor fort det ble atrofi i m. vastus medialis i kneet ved akutte kneskader, førte til at jeg ble opptatt av leddbevegelsen, muskelkraften og leddsansen i forbindelse med rådgivning om treningsopplegg ved leddskader. Flere pasienter som hadde fulgt mine råd om turer i utmark for å trene opp bevegelsen, kunne fortelle det samme som han som måtte se ned når han gikk i utmark det tar lengre tid å trene opp balansen enn leddbevegelsen. Pasientene med akutte skader fikk derfor beskjed om at det tok 3-4 måneder med trening før leddsansen var normalisert, selv om muskelkraft og bevegelighet var normale etter få uker.

De samme treningsretningslinjene har jeg god erfaring med ved kroniske plager som ved artrose og artritt. Disse plagene fører vanligvis til nedsatt bevegelse i leddene og redusert kraft i den leddnære muskulaturen. Leddsansen blir også gradvis redusert. Treningen ved 
kroniske plager må da bli en form for aktivitet man kan drive med 3-4 ganger i uken for å prøve å hindre denne utviklingen $(1,2)$.

Øvelsene må være så enkle og ta så kort tid at det er lett for alle å tilpasse treningen til vanlige daglige rutiner. Derfor blir det viktig å finne frem til aktiviteter som pasientene trives med og klarer å gjennomføre og som gir ønsket effekt på bevegelse, styrke og leddsans i de områdene som de har plager fra.

LITTERATUR:

1. Måseide T. Artrose kan behandles på flere måter. Tidsskr Nor Legeforen 2013; 133: 1062. [PubMed][CrossRef]

2. Bätre omhändertagande av patienter med artros (BOA). https://boa.registercentrum.se (13.3.2018).

Publisert: 17. april 2018. Tidsskr Nor Legeforen. DOI: 10.4045/tidsskr.18.0223

Mottatt 7.3.2018, godkjent 13.3.2018.

(C) Tidsskrift for Den norske legeforening 2020. Lastet ned fra tidsskriftet.no 